\title{
What's Happened at Divested Bank Offices? An Empirical Analysis of Antitrust Divestitures in Bank Mergers
}

\author{
Steven J. Pilloff* \\ Board of Governors of the Federal Reserve System \\ Washington, DC 20051
}

December 2002

\begin{abstract}
In their competitive analysis of proposed bank mergers, the Federal Reserve Board, Department of Justice, and other agencies accept branch divestitures as an antitrust remedy in local markets where there is substantial overlap between the acquirer and target. The results of this study, which examines the performance of 751 branches that were divested between June 1989 and June 1998 in conjunction with a merger that raised possible competition issues, suggest that the policy of accepting branch divestitures as an antitrust remedy has been successful. Divested branches operate for lengths of time that are comparable to all branches, and even though they experience substantial deposit runoff around the time of the merger, divested branches subsequently exhibit deposit growth rates that are comparable to those of other similar branches. Cross-sectional analysis does not find any significant relationships between either deposit runoff or subsequent growth and various characteristics of the branch being sold or the firm that purchased it, except for some evidence that post-divestiture growth may increase with the size of the purchaser.
\end{abstract}

*I would like to thank Dean Amel, Robin Prager, and attendees of a seminar sponsored by the Financial Institutions Committee of the Antitrust Section of the American Bar Association for helpful comments and Charles Taragin for excellent research assistance. I am also extremely grateful to Rich Gebert of the Department of Justice for providing me with valuable information on the identity of divested offices. This views expressed in this paper are the author's and do not reflect those of the Board of Governors of the Federal Reserve System or its staff. The author can be reached at 202-736-5622 (phone) or spilloff@frb.gov (e-mail). 


\section{Introduction}

Over the past two decades, the banking industry has experienced an unprecedented level of consolidation. ${ }^{1}$ Merger activity has been particularly intense over the latter half of this period. For example, more than 4,400 bank mergers, involving the acquisition of almost $\$ 2.9$ trillion in total deposits, took place between 1990 and 2001 . $^{2}$ This immense consolidation substantially changed the structure of the banking industry. For example, between 1990 and 2001, the number of commercial banking organizations decreased by nearly 30 percent to roughly 6,600, and the share of assets and deposits controlled by the largest banks increased substantially. The 25 largest commercial banking organizations held 35 percent of domestic deposits in 1990, but by 2001, that figure had grown to 55 percent. $^{3}$

Even though banking has undergone large structural changes at an industry-wide level, structural measures at the local level suggest that a substantial decline in competition has probably not taken place. Antitrust authorities have defined retail banking markets to be local in nature. Many studies of bank performance use the local area as the relevant geographic market definition, and results from these studies are frequently consistent with banking markets being local. ${ }^{4}$ In addition, the most recent of the Federal Reserve Board's Survey of Consumer Finances (1998) and Survey of Small Business Finances (1998) indicate that households and small businesses continue to rely heavily on local financial institutions, especially commercial banks. Bank and thrift offices have remained important, increasing in number from about 84,000 in 1990 to roughly 87,000 in $2001 .^{5}$

Between June 1990 and June 2001, the average Herfindahl-Hirschman index (HHI), based on commercial banking deposits, decreased in both metropolitan statistical

\footnotetext{
${ }^{1}$ Throughout this paper, unless noted otherwise, the banking industry refers to both commercial banks and savings institutions. In addition, the terms merger and acquisition are used interchangeably, and the term branch is used to refer to any bank or thrift deposit-taking office.

${ }^{2}$ Merger data were obtained from the SNL Financial Bank Mergers and Acquisitions database.

${ }^{3}$ Concentration data are as of year-end and were obtained from the National Information Center and Reports of Condition and Income.

${ }^{4}$ For example, see Pilloff and Rhoades (2002), Pilloff (1999), Berger and Hannan (1998), Hannan and Prager (1998), Hannan (1997), Kamerschen and Frame (1997), Hannan and Liang (1995), and Rhoades (1995).

${ }^{5}$ Data on the number of offices at FDIC-insured commercial banks and savings institutions are as of yearend and were obtained from the FDIC.
} 
areas (MSAs) and non-MSA counties. When the deposits of thrifts are included in calculations at 50 percent, which is consistent with the approach typically taken by the Federal Reserve Board in its competitive analysis of bank mergers, the data continue to suggest that competition has not been substantially reduced. The average HHI in nonMSA counties declined slightly, and although the MSA average increased by 140 points, the average level in 2001 was roughly 1600, suggesting that concentration has remained moderate and, therefore, competition has been at least reasonably strong. ${ }^{6}$

How could the banking industry have experienced so much consolidation, yet not have experienced a large decline in competition at the local level? First, many bank mergers involved banks with operations in different geographic areas. These deals may have reduced the number of organizations in the industry and may have raised concentration at the national level, but because they did not alter the structure of local markets, they did not reduce competition at the local level.

However, many deals involved banks with geographic overlap. If certain of these transactions had been permitted to proceed without modification, the result would have been large increases in and high levels of concentration, and large market shares held by the consolidated firm. To avoid these anticompetitive structural effects, banks have divested branches. By divesting a relatively small number of branches in markets with extensive overlap, banks have been able to eliminate possible competitive problems raised by mergers and complete a substantial number of deals, including numerous large ones that have transformed the industry.

The basics of a branch divestiture are simple: Within 180 days of the primary merger being consummated, one or more branches (and all associated deposits and loans) are sold to another financial institution that subsequently owns and operates those branches. Customers of the divested branch typically receive a letter in the mail explaining that the branch that holds their account has been purchased by another financial institution, and that they are now customers of that other bank or thrift. The level of deposits that are divested is sufficiently large that the increase in and resulting level of concentration in the market and the post-merger market share of the consolidated

\footnotetext{
${ }^{6}$ Under the Department of Justice Merger Guidelines, a market is considered unconcentrated if the HHI is under 1000 , moderately concentrated if the $\mathrm{HHI}$ is between 1000 and 1800 , and highly concentrated if the $\mathrm{HHI}$ is more than 1800 .
} 
organization are low enough to satisfy the concerns of antitrust authorities and bank regulators.

A critical element of divestitures being an effective tool for antitrust policy is that the firm that purchases a divested branch be able to operate it effectively. By retaining and attracting customers, a divested branch can remain a viable option for banking customers and can therefore exert a pro-competitive influence on the market. If divested branches do not retain and attract customers, then they are unlikely to provide a strong competitive presence, thereby leading to a lower level of competition in the market.

In this paper, the issue of how divested branches have performed is examined. The length of time that divested branches operate after being sold and changes in deposit levels are measured for a sample of 751 bank and thrift branches that were divested between June 1989 and June 1999. In addition, cross-sectional analysis is conducted to see if any important characteristics have been associated with deposit growth at divested branches. The only other study that empirically examines the performance of divested branches is Burke (1998), which examined 210 branches divested in association with deals completed between 1985 and 1992.

Analysis indicates that the share of divested branches that operated for at least a certain number of years following divestiture is generally not substantially different from the share of other, similar branches that operated for a comparable length of time. Changes in the level of deposits held at divested branches, however, show a distinct pattern that differs from other branches. Divested branches lost almost 13 percent of their deposits in the period spanning the June immediately preceding the merger to the June following divestiture, which is significantly different than the positive median growth rate experienced among all branches and the negative, yet smaller in magnitude, growth rate of branches that were acquired, but not divested. After this initial "runoff period," divested branches exhibit deposit growth that is generally comparable to other branches. Regression results indicate that deposit growth during the initial runoff period was not related to whether the branch belonged to the surviving organization, whether the purchaser was an in-market or out-of-market firm, whether the purchaser was a savings institution or a commercial bank, or the overall size of the branch purchaser. Results are similar for the two- and three-year periods following the runoff period, except that 
deposit growth increased with the size of the purchaser during the first three years following divestiture.

The issue of whether divestitures have had a procompetitive effect in markets affected by potentially anticompetitive mergers is important and timely. The Federal Trade Commission (FTC) and Department of Justice (DOJ) commonly rely on divestitures to remedy possible anticompetitive harm associated with proposed mergers in a variety of industries. The importance of the issue is underscored by a recent report released by the General Accounting Office in September 2002 that specifically recommends that the FTC undertake a study to assess the effectiveness of recent divestitures in retail markets. The results based on the performance of divested bank branches presented in this paper make a valuable contribution to better understanding the issue of whether divestitures are an effective remedy for potentially anticompetitive mergers.

\section{Divestiture Policy: DOJ and FRB Approaches}

An effective divestiture policy must incorporate several elements. First, the level of deposits and loans to be sold must be specified, in addition to identifying which deposits and loans are to be divested. The analysis in this paper does not directly address these elements of divestiture policy. A second, and not altogether unrelated, element is determining which branches should be sold. Characteristics that may be important include whether or not the branch originally belonged to the firm that survives the merger, the location of the branch, and the composition of the branch's asset and deposit portfolios. A third aspect of a divestiture policy is determining which firms can and should purchase branches. A key issue related to this aspect is whether one firm should purchase all of the divested branches in a market. Other key issues involve whether the purchaser should already have a presence in the market, be a bank or a thrift institution, or be of a certain size.

The Federal Reserve Board (FRB) and the Department of Justice (DOJ) are the two agencies most heavily involved in evaluating the competitive effects of proposed bank mergers and overseeing the divestiture of branches. The FRB must approve or deny all mergers in which the resulting firm would be a bank holding company or a state 
member bank. The DOJ has enforcement powers and can investigate and challenge any proposed bank merger that it chooses. To prevent the FRB from denying or the DOJ from blocking a proposed acquisition, bank acquirers frequently propose divestitures to reduce competitive concerns raised by a planned merger. Both agencies have divestiture policies whereby they require, or in some cases prefer, divestiture packages to exhibit certain characteristics.

The Department of Justice takes a very active role in the divestiture process. ${ }^{7}$ One of their main concerns is minimizing runoff at divested branches, which occurs when depositors at such offices close their accounts and move their funds elsewhere. Runoff can take place either before or after the actual divestiture takes place. The DOJ generally requires that divested branches belong to the firm that will not survive the merger, typically the target, so that depositors do not have the opportunity to reopen their accounts at another branch of their former institution. The DOJ will oftentimes accept a "clean-sweep" divestiture of acquirer branches in which all acquirer branches in a market are divested. However, the agency generally opposes divestiture packages that include both acquirer and target branches, as such packages typically involve facilities that operate under different accounting, computer, and other systems, making them especially difficult for a purchaser to integrate.

The Justice Department has several other requirements that are intended to minimize deposit runoff. First, the acquirer from the primary merger is prohibited from soliciting customers of branches that are being divested. Moreover, banks cannot transfer customer accounts from a divested branch to a non-divested branch without receiving special permission. $^{8}$

The Justice Department also closely looks at the location and activity of divested branches. They prefer that branches be sold that provide the purchaser with good

\footnotetext{
${ }^{7}$ The discussion of the divestiture policy of the Department of Justice is based largely on Neill (2001) and the handouts that accompanied a presentation by J. Robert Kramer II and Erin Carter Grace on "Recent Issues Concerning Divestitures in Bank Mergers" that was given on May 9, 2001, at a seminar sponsored by the Financial Institutions Committee of the Antitrust Section of the American Bar Association. Discussion of the divestiture policy of the Federal Reserve Board is based in part on Neill (2001) and Burke (1998). Some aspects of current divestiture policy may not be relevant for earlier portions of the sample period analyzed in this paper.

${ }^{8}$ In some cases, with the agreement of the Department of Justice and the Federal Reserve Board, certain customer accounts that are affiliated with a divested branch are not included in the divestiture. These customers generally account for a small portion of a branch's total level of business activity.
} 
geographic coverage of an area. Because branch location is important to bank customers, good geographic coverage enables banks to appeal to a large portion of an area. The DOJ also wants branches to be in areas with commercial activity, especially small business activity. Moreover, the branches themselves are generally required to be sufficiently involved in commercial activity. The DOJ further encourages the divestiture of branches that are owned, not leased, and branches that have sufficient facilities to adequately serve bank customers.

The Department of Justice is not only concerned with which branches are sold, but with who buys them. The DOJ typically requires that a single firm purchase all divested branches in a market. Because they are especially concerned with the effect of mergers on small business lending, the DOJ prefers that the purchaser be active in commercial lending. In other words, the purchaser must be either a commercial bank or a thrift with at least 2 percent of its assets held as commercial loans. The DOJ further assesses the suitability of a potential buyer by looking at its business plan, product offerings, staffing, and backroom support capabilities. The DOJ also takes into consideration whether the purchaser already has a market presence or whether it would be a new competitor in the market, but the agency's preference depends on the specific issues of the case.

The DOJ has a number of other provisions to its divestiture policy that are intended to help make divestitures effective. Among them is the requirement that banks assign each customer to a single branch and then assign all of that customer's accounts to that single office. In this way, all of a customer's accounts are either included in or excluded from a divestiture, making runoff, in their opinion, less likely. The DOJ wants to avoid situations such as a customer having a checking account at a non-divested branch, but a certificate of deposit and a home equity loan at a divested branch. In a situation like this, the customer would hold accounts at two banks and it is believed that the customer would be more apt to consolidate all accounts at one institution. The DOJ requires banks to assign a customer to the branch that is used most frequently (typically the branch that houses the customer's checking account). By doing this, runoff may be kept to a minimum, as the incentive to move accounts out of the divested branch is reduced. 
The Federal Reserve Board gets much less involved than the Department of Justice with the specifics of the divestiture process. The Board's primary concern is the size of the divestiture and its effect on the structure of the market. One preference of the Board is that divestiture packages be sold to out-of-market firms because a divestiture to a firm without an existing presence results in the number of firms remaining unchanged, and research studies have found that the number of competitors in a market is a significant characteristic associated with the level of competition in the market. ${ }^{9}$ Even though the Board requires that a branch and all associated deposits and loans be divested, it is much less involved than the DOJ in dictating to banks how to determine which loans are "associated" with a given branch.

\section{Sample of Divested Branches}

The analysis in this paper examines 751 bank and thrift offices that were divested between June 1989 and June 1999 in conjunction with mergers that raised possible antitrust concerns. The divested offices were identified from a number of sources, including letters from the Department of Justice to bank regulators, Federal Reserve Board Orders, lists of divested branches provided by participating banks, and year-toyear comparisons of the Summary of Deposits (SOD), which reports deposits of all individual bank and thrift offices as of June 30 of each year.

After identifying the divested branches, annual deposit levels for each branch were collected from SOD reports. One year of pre-merger data was collected for each branch from the June preceding consummation of the merger. In calendar time, the premerger year ranged from 1989 to 1998, and in event time, this pre-merger year is referred to as year 0 .

Post-divestiture data were collected for as many years as possible until 2001, the last year for which SOD data were available at the time the dataset was constructed. In about 55 percent of the observations, the first post-divestiture observation is for the year immediately following the pre-merger year. In these cases, both the merger and divestiture were completed between the pre-merger June and the following June.

\footnotetext{
${ }^{9}$ For example, see Pilloff and Rhoades (2002).
} 
With the other 45 percent of sample branches, the first post-divestiture observation reflects deposits from two years after the pre-merger observation. In these cases, the merger was completed before the June following the pre-merger year, but divestitures were not completed until after the June SOD was filed. Therefore, the acquirer from the primary merger owned the divested branch in the year immediately following the pre-merger year, and the eventual purchaser owned the branch by the next year. The first post-divestiture year is referred to as year 1, regardless of whether it is one or two years after the pre-merger year, and subsequent years are referred to as year 2, year 3 , etc.

To be included in the sample, a divested branch must be observable on the premerger SOD and the first post-divestiture SOD. Branches that could not be tracked either immediately before or after the merger were excluded. In addition, branches that were divested after the first June following the merger also had to be observable on the postmerger, pre-divestiture SOD. Because all sample divestitures took place by June 1999, there were at least three possible post-divestiture observations for each branch (1999, 2000, and 2001).

Divested branches were tracked over time by matching addresses reported on the SOD. In many cases, however, the reported address associated with a divested branch changed over time, especially at the time of divestiture or some other subsequent merger activity. Lists of divested branches (often with deposits and frequently provided by the Department of Justice), personal judgment, and telephone calls to staff at various branches were used to determine the cause of the change in the reported address. If the different addresses referenced the same facility, then the same branch was considered to have operated during the time period. ${ }^{10}$ However, if the facility was different, even if it was because the bank moved to a larger and better office next door, the office was not considered the same, and the original branch was considered to have stopped operating.

The 751 branches were divested in 219 counties in 37 states in conjunction with 58 different mergers. There was a large range in the number of divested branches that the

\footnotetext{
${ }^{10}$ A great deal of effort was spent matching the 751 divested branches over time. A few examples of branches with different addresses for the same facility are the following: 2183 Park Avenue is the same office as Park and Milwaukee Avenues, 65 Lake Mead Drive is the same as 65 West Lake Mead Drive, and 2000 Market Street is the same as $20^{\text {th }}$ and Market Streets.
} 
counties contribute to the sample with many counties contributing few branches and a small number of counties contributing many branches. Approximately 40 percent of the counties contribute only a single divested branch to the sample, and another 20 percent of the counties contribute two branches. In contrast, a few urban counties were home to large divestitures and therefore account for a disproportionate share of the branches in the sample. In five of the counties represented in the sample, at least 20 (but no more than 31) branches were divested. There are four different acquisitions represented by these sizable divestitures.

Table 1 presents a list of the acquisitions that contribute the largest number of branches to the sample. Clearly, branches divested by BankAmerica Corporation as part of its acquisition of Security Pacific Corporation in early 1992 account for the largest share of the branches in the sample. Nearly 190 branches, or roughly one-fourth of the sample are associated with this deal. Other deals that contributed a large, albeit much smaller, share of the divested branches include NationsBank-Barnett (65 branches), FleetShawmut (63), and Wells Fargo-First Interstate (53). Most of the deals represented in the sample are associated with only a few divested branches. Roughly 30 percent of the 58 deals contribute a single branch and another 30 percent contribute two or three branches to the sample.

Eighty-six different firms purchased divested branches. Two firms acquired more than 50 of the sample branches, and another two purchased more than 40 offices. Moreover, nine banks and thrifts purchased between 20 and 40 branches. In contrast to these substantial acquisitions of divested branches, there were 28 purchasers that acquired a single office and twelve that purchased two offices.

The mergers that are represented by the sample took place roughly over the decade of the 1990s. For about one-third of the sample, the pre-merger observation is as of June 1991. These deals are largely attributable to Bank of America-Security Pacific, but other deals, including Society-Ameritrust, also contributed to the large total. June 1995 and June 1997 are also common pre-merger dates, with slightly more than 20 percent of the sample having each of these as its pre-merger date. 
Table 1

Acquisitions and Number of Divested Branches in Sample

\begin{tabular}{|l|l|l|l|r|}
\hline Rank & Acquiring Firm & Target Firm & Date & Branches \\
\hline 1 & BankAmerica Corporation & Security Pacific Corporation & 19920422 & 187 \\
2 & NationsBank Corporation & Barnett Banks, Inc. & 19980109 & 65 \\
3 & Fleet Financial Group & Shawmut National Corporation & 19951130 & 63 \\
4 & Wells Fargo \& Company & First Interstate Bancorp & 19960401 & 53 \\
5 & Banc One Corporation & First Chicago NBD Corporation & 19981002 & 39 \\
6 & First Union Corporation & CoreStates Financial Corp & 19980428 & 34 \\
7 & Society Corporation & Ameritrust Corporation & 19920316 & 33 \\
8 & U.S. Bancorp & West One Bancorp & 19951227 & 26 \\
9 & Banc One Corporation & First Commerce Corporation & 19980612 & 24 \\
10 & Norwest Corporation & Wells Fargo \& Company & 19981102 & 22 \\
11 & Southern National Corporation & United Carolina Bancshares Corp & 19970701 & 21 \\
12 & Bank of Boston Corporation & BayBanks, Inc. & 19960729 & 20 \\
13 & NationsBank Corporation & BankAmerica Corporation & 19980930 & 15 \\
14 & First Union Corporation & Florida National Banks of Florida & 19900129 & 11 \\
15 & KeyCorp & 19950216 & 11 \\
16 & Marshall \& Ilsley Corporation & Casco Northern Bank & 19940531 & 10 \\
17 & Southern National Corporation & Valley Bancorporation & 19950228 & 10 \\
18 & CoreStates Financial Corp & Meridian Bancorp, Inc. & 10 \\
19 & Wachovia Corporation & Central Fidelity Banks, Inc. & 19971215 & 8 \\
20 & NCNB Corporation & C\&S/Sovran Corporation & 19911231 & 7 \\
21 & First Of America Bank Corporation & Security Bancorp & 19920501 & 7 \\
22 & United New Mexico Financial Corp & First Interstate Bancorp & 19910515 & 6 \\
$23-25$ & 3 Acquisitions with 4 Branches & & & 12 \\
$26-33$ & 8 Acquisitions with 3 Branches & & & 24 \\
$34-41$ & 8 Acquisitions with 2 Branches & & & 17 \\
$42-58$ & 17 Acquisitions with 1 Branch & & & 751 \\
\hline & Total for 58 Acquisitions & & & \\
\hline
\end{tabular}




\section{Analysis: Survival Rates}

The first type of analysis conducted in this study is an examination of survival rates, which are defined as the percentage of divested branches that operated for at least a given number of years following divestiture. Panel A of table 2 presents a complete survival rate analysis for the 751 divested branches in the sample. The first column indicates the year of the first post-divestiture SOD for the branches described in each row (except the last two rows). The second column reports the number of branches in the sample that had a given year as their first post-divestiture year. Finally, the last twelve columns report how many branches survived at least a given number of years following divestiture. Panel B reports the information as a share of the figure reported in column two.

For example, the second row reports information on the 108 branches that had 1998 as the year of their first post-divestiture SOD. The table indicates that, consistent with sample construction rules, all of the branches were in operation for the first possible post-divestiture year. Three of the branches were not in operation during the second possible post-divestiture year (1999), leaving 105 surviving branches. Panel B indicates that 105 branches correspond to 97 percent of the 108 that could have operated during the second year following divestiture. The table also indicates that 102 branches (94 percent) survived at least to the third year (2000) and 98 branches (91 percent) operated during the fourth and final post-divestiture period (2001).

The second last row of panel A reports the number of branches that survived at least the number of years following divestiture indicated by the number in the column heading, and the last row reports the number of branches that could have survived at least that number of years. The number of possible branches that corresponds to each of the figures in the second last row varies, because the number of branches that could have survived at least a given number of years decreases as the possible number of years increases. For example, all 751 branches could have operated during the second post-divestiture year, but only 316 branches could have operated during the seventh year following divestiture. Of the 316 branches, 213 (67 percent) operated during that seventh year.

What do the figures in table 2 tell us about how long divested branches continued to operate after being divested? They seem to suggest that divested branches were very likely to continue operating from year-to-year. Roughly 97 percent of the divested branches operated at 
Table 2

Survival Data for Divested Branches

\begin{tabular}{|c|c|c|c|c|c|c|c|c|c|c|c|c|c|}
\hline \multirow{2}{*}{$\begin{array}{l}\text { First Post- } \\
\text { Divestiture } \\
\text { Year }\end{array}$} & \multirow{2}{*}{$\begin{array}{l}\text { Number of } \\
\text { Divested } \\
\text { Branches }\end{array}$} & \multicolumn{12}{|c|}{ Panel A: Number of Divested Branches in Operation At Least a Given Number of Years Following Divestiture } \\
\hline & & 1 & 2 & 3 & 4 & 5 & 6 & 7 & 8 & 9 & 10 & 11 & 12 \\
\hline 1999 & 141 & 141 & 139 & 134 & & & & & & & & & \\
\hline 1998 & 108 & 108 & 105 & 102 & 98 & & & & & & & & \\
\hline 1997 & 76 & 76 & 72 & 59 & 52 & 52 & & & & & & & \\
\hline 1996 & 110 & 110 & 107 & 101 & 98 & 92 & 90 & & & & & & \\
\hline 1995 & 42 & 42 & 40 & 39 & 33 & 32 & 28 & 26 & & & & & \\
\hline 1994 & 13 & 13 & 13 & 12 & 12 & 11 & 11 & 10 & 10 & & & & \\
\hline 1993 & 201 & 201 & 192 & 171 & 152 & 145 & 137 & 133 & 125 & 122 & & & \\
\hline 1992 & 42 & 42 & 42 & 42 & 39 & 35 & 34 & 31 & 31 & 31 & 30 & & \\
\hline 1991 & 6 & 6 & 4 & 3 & 3 & 3 & 3 & 3 & 3 & 3 & 3 & 3 & \\
\hline 1990 & 12 & 12 & 12 & 12 & 12 & 12 & 12 & 10 & 9 & 9 & 9 & 8 & 8 \\
\hline All Years & 751 & 751 & 726 & 675 & 499 & 382 & 315 & 213 & 178 & 165 & 42 & 11 & 8 \\
\hline \multicolumn{2}{|c|}{ Possible \# of branches } & (751) & (751) & (751) & (610) & (502) & (426) & (316) & (274) & (261) & (60) & (18) & (12) \\
\hline
\end{tabular}

\begin{tabular}{|c|c|c|c|c|c|c|c|c|c|c|c|c|c|}
\hline \multirow{2}{*}{$\begin{array}{l}\text { First Post- } \\
\text { Divestiture } \\
\text { Year }\end{array}$} & \multirow{2}{*}{$\begin{array}{l}\text { Number of } \\
\text { Divested } \\
\text { Branches }\end{array}$} & \multicolumn{12}{|c|}{ Panel B: Percent of Divested Branches in Operation At Least a Given Number of Years Following Divestiture } \\
\hline & & 1 & 2 & 3 & 4 & 5 & 6 & 7 & 8 & 9 & 10 & 11 & 12 \\
\hline $\begin{array}{l}1999 \\
\end{array}$ & 141 & 100 & 99 & 95 & & & & & & & & & \\
\hline 1998 & 108 & 100 & 97 & 94 & 91 & & & & & & & & \\
\hline 1997 & 76 & 100 & 95 & 78 & 68 & 68 & & & & & & & \\
\hline 1996 & 110 & 100 & 97 & 92 & 89 & 84 & 82 & & & & & & \\
\hline 1995 & 42 & 100 & 95 & 93 & 79 & 76 & 67 & 62 & & & & & \\
\hline 1994 & 13 & 100 & 100 & 92 & 92 & 85 & 85 & 77 & 77 & & & & \\
\hline 1993 & 201 & 100 & 96 & 85 & 76 & 72 & 68 & 66 & 62 & 61 & & & \\
\hline 1992 & 42 & 100 & 100 & 100 & 93 & 83 & 81 & 74 & 74 & 74 & 71 & & \\
\hline 1991 & 6 & 100 & 67 & 50 & 50 & 50 & 50 & 50 & 50 & 50 & 50 & 50 & \\
\hline 1990 & 12 & 100 & 100 & 100 & 100 & 100 & 100 & 83 & 75 & 75 & 75 & 67 & 67 \\
\hline All Years & 751 & 100 & 97 & 90 & 82 & 76 & 74 & 67 & 65 & 63 & 70 & 61 & 67 \\
\hline
\end{tabular}


least two post-divestiture years, and year-to-year survival rates were roughly on the order of 90 to 95 percent for subsequent years.

Although the figures on divested branches are interesting, they do not tell us how the survival rates of divested branches compared to other branches. Did divested branches operate for periods that were shorter, longer, or about the same as all branches? Seeing that divested branches operated for a length of time that is at least comparable to the typical branch would be consistent with divestitures having been effective, because it would suggest that divested branches have been able to operate as successfully as other branches. To address this important issue, benchmark figures were constructed.

Survival rates for benchmark banks were created in a rather straightforward manner. For each year of data, 1989 to 1998, all branches on the SOD with a reported address were tracked forward by looking at how many consecutive years each address appeared on the SOD. As soon as an address does not exist on the SOD or is associated with zero deposits, the branch was considered to have stopped operating.

In order to maximize the number of accurate matches that could be identified, several steps were taken to try and make addresses uniform across time including dropping all punctuation and spelling out common words and numbers. Although these steps helped generate between 50,000 and 64,000 matches per two-year period, the efforts were nonetheless somewhat limited in identifying all appropriate branch matches over time. Sometimes, a reported address referencing a particular facility changed, even though the actual physical structure remained the same. $^{11}$

To make the benchmark similar to the sample, every branch in the benchmark group was classified as being in one of the nine Census divisions and in either a rural or urban area. Urban areas were defined as counties in metropolitan statistical areas using 1999 definitions. Then, survival rates were measured for each of the eighteen division-urban/rural combinations in the same way that they were measured for the 751 divested branches as reported in panel B of table 2. A weighted average of the eighteen sets of survival rates was then taken using the number of divested branches in each division-urban/rural combination as the weight to get the benchmark survival rates. The number of years that took place between pre-merger and post-divestiture was

\footnotetext{
${ }^{11}$ As discussed earlier, a great deal of effort was spent tracking the 751 divested branches over time. Due to resource limitations, similar care could not be taken with the tens of thousands of benchmark offices.
} 
also taken into account with the appropriate weighting. ${ }^{12}$ Benchmark survival rates are presented in table 3 .

The most relevant comparison is to look at survival rates for all branches that could have survived at least a given number of years following divestiture. The figures for such a comparison are provided in the last several rows of table 3. The table indicates that whereas 97 percent of the sample branches survived at least two post-divestiture years, only 93 percent of the benchmark banks survived a comparable period. The three-year survival rates show a similar pattern, with 90 percent of divested branches surviving versus 87 percent of the benchmark branches.

Although these two differences are statistically significant and suggest that divested branches were more likely to continue operations after two or three years than other comparable branches, it is difficult to draw any strong conclusions. Matching branches over time is a timeconsuming process and much more effort was given to matching the 751 divestiture branches than the tens of thousands of benchmark branches. Moreover, the difference between the sample and benchmark survival rates is generally insignificant for post-divestiture periods of time greater than three years. After comparing the magnitude of differences between the sample and benchmark survival rates and taking into account the difficulties with tracking branches with the SOD over time, the data seem to suggest that divested branches tended to operate for roughly as long as other branches in the industry.

An important caveat to the survival analysis is that it takes a narrow view of the operating status of a branch. There are many reasons that a facility might discontinue operating and more than a few of them are not associated with the banking office being unsuccessful. A bank may close an older branch and open a newer, larger one nearby to better serve a growing and profitable customer base. In this case, the old branch would have discontinued operations because it had been "too successful." Another reason that a bank may close a branch is costreducing consolidation. A bank may wind up with two branches in the same area (often as a

\footnotetext{
12 Benchmark survival rates were computed in two ways. First, all branches on the SOD were initially included for each year. Then, only branches that could be tracked during the following year were kept. This condition was comparable to requiring divested branches to be observable before the merger and after the divestiture. This process was repeated for each year, 1989 to 1998. The second approach was to include all branches that could be tracked for three consecutive years. Survival rates between the first and last of these three years were treated as one-year rates to be comparable to those of divested branches that had a two-year gap between the pre-merger SOD and the postdivestiture SOD.
} 
Table 3

Survival Rates for Benchmark Branches

\begin{tabular}{|c|c|c|c|c|c|c|c|c|c|c|c|c|c|}
\hline \multirow{2}{*}{$\begin{array}{l}\text { First Post- } \\
\text { Divestiture } \\
\text { Year }\end{array}$} & \multirow{2}{*}{$\begin{array}{l}\text { Number of } \\
\text { Divested } \\
\text { Branches }\end{array}$} & \multicolumn{12}{|c|}{ Percent of Benchmark Branches in Operation At Least a Given Number of Years Following Acquisition } \\
\hline & & 1 & 2 & 3 & 4 & 5 & 6 & 7 & 8 & 9 & 10 & 11 & 12 \\
\hline 1999 & 141 & 100 & 95 & 89 & & & & & & & & & \\
\hline 1998 & 108 & 100 & 90 & 85 & 78 & & & & & & & & \\
\hline 1997 & 76 & 100 & 91 & 83 & 79 & 76 & & & & & & & \\
\hline 1996 & 110 & 100 & 89 & 81 & 76 & 72 & 67 & & & & & & \\
\hline 1995 & 42 & 100 & 94 & 85 & 79 & 73 & 69 & 65 & & & & & \\
\hline 1994 & 13 & 100 & 95 & 90 & 82 & 76 & 69 & 66 & 62 & & & & \\
\hline 1993 & 201 & 100 & 95 & 91 & 86 & 76 & 70 & 66 & 63 & 60 & & & \\
\hline 1992 & 42 & 100 & 96 & 92 & 88 & 84 & 78 & 73 & 68 & 65 & 61 & & \\
\hline 1991 & 6 & 100 & 96 & 93 & 91 & 89 & 85 & 78 & 73 & 72 & 70 & 68 & \\
\hline 1990 & 12 & 100 & 95 & 89 & 80 & 74 & 70 & 65 & 57 & 53 & 49 & 47 & 43 \\
\hline All Years & & 100 & 93 & 87 & 82 & 76 & 70 & 67 & 64 & 61 & 60 & 54 & 43 \\
\hline
\end{tabular}

82

76

74

67

65

63

$70 \quad 61$

Difference

$0.0 \quad 3.7^{\mathrm{a}}$

$2.8^{\mathrm{b}}$

0.2

0.2

$3.9^{\mathrm{c}}$

0.6

1.2

2.2

10.3

7.3

$23.9^{\mathrm{c}}$

Note: a (b,c) indicates significant difference between the sample and benchmark at the 1 percent (5 percent, 10 percent) level. 
result of a merger) and may close one to save on costs. The decision may have nothing to do with the ability of the closed branch to serve its customers. Therefore, it is important to keep in mind that while the survival rate analysis provides us with relevant and interesting information about post-divestiture performance, there are limits in the strength of any conclusions that can be drawn.

\section{Analysis: Growth}

The second type of analysis is an examination of deposit growth. If a divested branch is able to retain and attract deposits, then it is more likely that customers view it as an attractive alternative, and it is more likely that the branch provides effective competition. The rate at which a branch is able to grow its deposits provides insight into its ability to meet customer needs.

Growth was measured for various periods for every divested branch in the sample. Median values are reported in table 4. The second column of the table reports the number of banks that could have survived at least the number of post-divestiture years listed in column one, and the third column lists the number of branches that actually survived that long. The remainder of the columns report the median growth rates over different periods experienced by branches that operated at least as long as the relevant number of post-divestiture years. The last column reports median cumulative growth rates during the post-divestiture period and the preceding columns report one-year growth rates. ${ }^{13}$ For example, the median growth in deposits between the pre-merger year ( 0 ) and the first post-divestiture year (1) was -12.0 percent for the 675 branches that operated for at least three post-divestiture years. Following divestiture, the growth rate for these branches between years 1 and 2 was 1.3 percent and the growth rate between years 2 and 3 was 4.9 percent. The median cumulative growth rate during the two-year, post-divestiture period (year 1 to year 3) was 7.0 percent.

Median deposit growth rates are better suited than means to measuring the growth of the typical branch, because medians are not heavily influenced by outliers, whereas means are. By definition, positive growth rates are asymmetrically larger in magnitude than negative growth rates. The lowest value that growth can take is -100 percent, whereas the highest value has no

\footnotetext{
${ }^{13}$ In the analysis of growth rates, the post-divestiture period begins with year 1 . Therefore, for example, growth between years 1 and 4 is referred to as the three-year growth rate.
} 
Table 4

Growth Rates for Divested Branches

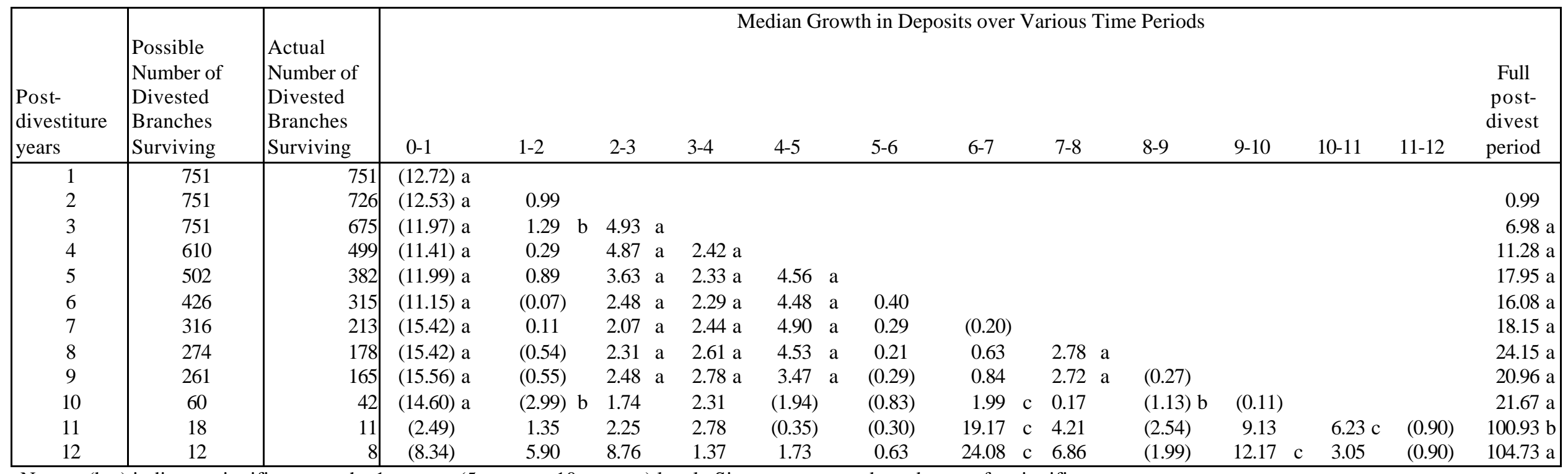

Note: a (b,c) indicates significance at the 1 percent (5 percent, 10 percent) level. Sign tests are conducted to test for significance. 
upper limit. Therefore, mean growth rates can be heavily influenced by a small number of extremely large values. For instance, there are numerous examples among benchmark branches of year-to-year growth rates exceeding 15,000 percent. These growth rates may represent reporting errors or may be the result of branch consolidation or deposit reallocation. Even if some or all of the outliers were a result of errors, it would be difficult to know which observations should be dropped and which should be kept. Using medians allows these outliers to be included in the analysis with only a limited influence on reported values. ${ }^{14}$

There is one clear pattern that emerges from table 4: divested branches lose a substantial share of deposits between the pre-merger and post-divestiture SOD reporting dates. About threequarters of the 751 branches lost deposits between years 0 and 1, with the median change being nearly - 13 percent. In subsequent years following divestiture, changes tended to be positive and more modest in magnitude. The data suggest that after initially losing a significant share of their deposits, the divested branches were able to reverse that pattern and grow.

Growth rates of divested branches must be examined relative to the growth rates experienced by similar branches throughout the industry. To do this, growth rate benchmarks are created in much the same way as survival rate benchmarks. Growth rates are measured over one- and multi-year time periods, starting from various points in time, for all branches in the benchmark group. Then, median growth rates are measured for the eighteen groups of branches based on the possible combinations of the nine Census divisions and the urban-rural split. The process is done twice; once with growth between year 0 and year 1 measured over a one-year period and once with growth between year 0 and year 1 measured over a two-year period.

Each of the 751 branches is matched with a relevant benchmark based on the year of the pre-merger SOD, the location of the branch, whether one or two years transpired between the pre-merger and post-divestiture periods, and the number of years that the branch operated. The difference between growth of divested branches and median growth of benchmark branches is computed to get adjusted growth rates. These rates reflect the performance of divested branches relative to similar branches. Median values of benchmark-adjusted growth rates are presented in table 5 .

\footnotetext{
${ }^{14}$ A simple example that illustrates the effect of the asymmetry on means is a branch that sees its deposits decline from $\$ 5$ million to $\$ 1$ million, and another branch that sees its deposits increase from $\$ 1$ million to $\$ 5$ million. The two growth rates would be -80 percent and 500 percent, respectively, which averages out to 210 percent. The two branches generate a very high average growth even though there is a total of $\$ 6$ million in both branches at both points in time.
} 
Table 5

Benchmark-Adjusted Growth Rates for Divested Branches

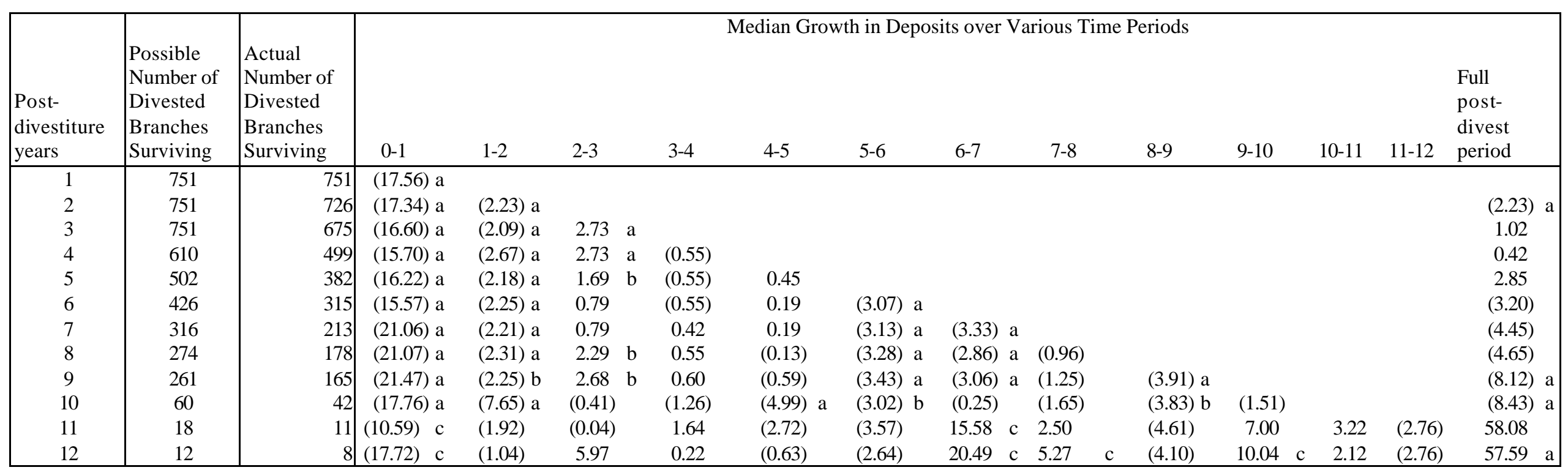

Note: a (b,c) indicates significance at the 1 percent (5 percent, 10 percent) level. Sign tests are conducted to test for significance. 
Examining runoff between the pre-merger and post-divestiture period relative to other branches suggests an even larger loss of deposits at divested branches. The median difference between growth of the 751 divested branches and growth at other branches was -17.6 percentage points. Because SOD data are reported once a year at a given point in time, we cannot tell when the runoff occurred. It is unclear from the data how much of this runoff took place before the merger, how much occurred between the merger and divestiture, and how much took place after divestiture. This information would shed light on the extent to which depositors fled in anticipation of the change in their bank and the extent to which depositors may not have been satisfied with the bank that purchased their branch. We also do not have information on what happened to the lost deposits, which would also provide valuable insight into the merger process and its effects on customers and other banks.

There is no clear pattern in deposit growth for years following the divestiture. Divested branches sometimes grew more rapidly and sometimes grew more slowly than other branches by a modest amount, and at other times they grew at about the same rate as other branches. Relative deposit growth was a statistically significant 2.2 percent below the benchmark between years 1 and 2 among the 726 branches that survived that long. However, it is unclear if this underperformance represents continued, albeit milder, runoff, or if it is simply part of a postdivestiture period during which divested branches did about as well as all branches on average with some yearly fluctuations.

Growth rates between the pre-merger and post-divestiture period presented in table 5 indicate that divested branches retained and attracted significantly fewer deposits than other, similar branches during this time of transition. However, the figures do not indicate how much of this reduction in deposits may be attributable to the disruption and inconvenience associated with the divestiture and how much may be attributable more generally to the merger.

Customers of any branch that undergoes a change in ownership generally experience some disruption or inconvenience in their banking activities because the new bank often institutes different policies and procedures, operates under new rate and fee schedules, and closes offices. Converting accounting, computer, and other systems from those of the former institution to those of the new institution can also introduce a myriad of problems. In addition, during the period immediately preceding the actual sale of their branch, customers may experience poor service from managers and owners who have little incentive to keep customers satisfied. As a 
result of changes and problems around the time a merger takes place, customers often flee their new bank for one that offers better service, prices, or convenience.

In order to distinguish between the effects of the merger and those of the divestiture on customer runoff, the growth rates of branches that were divested are compared to the growth rates of branches that were acquired in the same merger, but not divested. Specifically, for each divested branch in the sample that belonged to a target firm, the median growth rate between year 0 and year 1 is measured for all other target branches that were acquired, but not divested and that were located in the same census division and urban/rural area type as the divested branch. There were 598 divested branches that could be matched up with at least one other nondivested branch. Table 6 indicates that the median growth rate of these target-owned, divested branches was -11.7 percent between years 0 and 1 . In contrast, the median growth rate of benchmarks based on similar branches that were acquired, but not divested, was -6.8 percent. The median growth rate of benchmarks based on all similar branches to those that were divested was 4.8 percent.

These growth rates indicate that the decline in deposits observed during the so-called runoff period can be attributed to both the merger and the divestiture, with the merger accounting for about 70 percent of the difference and the divestiture for about 30 percent. The median growth rate of divested branches was about 16 percentage points less than the growth of all branches: roughly 5 percentage points of this amount are attributable to the difference between branches that were divested and branches that were acquired but not divested, indicating that about 11 percentage points are attributable to the difference in growth rates at branches that were acquired and all branches overall. When the minimum number of branches that must be included in the group of branches that were acquired, but not divested, is raised, the number of divested branches that can be analyzed decreases, but results remain similar.

These results suggest that the disruption and inconvenience for customers of a particular branch may be greater when the branch is divested as part of a bank merger than when the branch is included in the primary acquisition and not divested. Integrating branches acquired by divestiture may be more difficult than integrating other acquired branches, because such branch sales are less likely to involve executives, managers, and other staff of the acquired bank that may help smooth the transition process. Often, members of an acquired bank's management and staff are retained to assist in both the initial transition and ongoing operation of the consolidated 
Table 6

Growth Rates from Year 0 to Year 1

\begin{tabular}{|c|c|c|c|}
\hline \multirow[b]{2}{*}{ Measure } & \multicolumn{3}{|c|}{$\begin{array}{l}\text { Number of similar non-divested target branches owned by the } \\
\text { acquiring organization in the first post-divestiture year }\end{array}$} \\
\hline & At least 1 & At least 10 & At least 20 \\
\hline $\begin{array}{l}\text { Median growth in deposits of divested } \\
\text { target branches }\end{array}$ & $\begin{array}{l}-11.68 \\
\end{array}$ & -12.15 & -13.22 \\
\hline $\begin{array}{l}\text { Median growth in benchmark based on } \\
\text { deposits of non-divested target branches }\end{array}$ & -6.82 & -6.82 & -6.82 \\
\hline $\begin{array}{l}\text { Median growth in benchmark based on } \\
\text { deposits of all branches }\end{array}$ & 4.84 & 4.84 & 4.84 \\
\hline Median differences & & & \\
\hline $\begin{array}{l}\text { Divested less benchmark based on } \\
\text { all non-divested target branches }\end{array}$ & $-5.08 \mathrm{a}$ & $-4.93 \mathrm{a}$ & $-4.86 a$ \\
\hline $\begin{array}{l}\text { Divested less benchmark based on } \\
\text { all branches }\end{array}$ & $-16.44 a$ & $-17.08 \mathrm{a}$ & $-18.30 \mathrm{a}$ \\
\hline $\begin{array}{l}\text { Number of divested target branches in } \\
\text { deals with sufficient number of similar } \\
\text { nondivested target branches }\end{array}$ & 598 & 521 & 480 \\
\hline
\end{tabular}

Note: a $(b, c)$ indicates significant difference at the 1 percent (5 percent, 10 percent) level. Sign tests are conducted to test for significance. 
bank. Another possible explanation for why divested branches experience more runoff than other acquired branches is that divested branches may have been selected for sale by the acquiring firm because such branches were more likely to experience substantial runoff. However, it is unclear that runoff can be predicted accurately, and given that the divested branches must be sold to a willing buyer, it is also unclear that purchasers would be willing to repeatedly acquire branches that experience large amounts of deposit loss.

Annual growth rates indicate that after experiencing substantial runoff, divested branches grew comparably to other branches in the industry. This pattern suggests that divested branches tended to provide effective competition by being able to retain and attract deposits as well as other, similar branches. However, the pattern also suggests that divested branches were significantly smaller after divestiture than before. Roughly 70 percent of the size reduction appears to be associated with the branch being involved in an acquisition and an additional 30 percent appears to be associated with the branch being divested. As a result of the reduction in deposits, pre-merger deposit levels that do not take into account the likely high level of deposit runoff may overstate the influence of divested (and other acquired) branches on post-merger competition. This finding suggests that antitrust authorities and bank regulators may want to further examine the issue of whether to explicitly incorporate the effect of runoff into their competitive analysis of proposed bank mergers.

\section{Analysis: Regression}

The third type of analysis conducted in this study is regression analysis, which evaluates the relationship between deposit growth over various time periods and certain key characteristics of divestitures. Growth variables are adjusted to reflect the growth of comparable banks and are calculated as growth of the divested branch minus median growth of all similar branches over the same period of time.

The first dependent variable included in the analysis is the deposit growth rate observed between the pre-merger SOD date and the first post-divestiture SOD date. Growth over this period primarily measures deposit runoff associated with the transition, and regression analysis can help identify those variables that have been associated with more or less of it. The second dependent variable that is examined is post-divestiture growth between years 1 and 3 -the first two full years after divestiture. Every branch in the sample could have operated over this period, 
and 675 of them did. Although post-divestiture growth can be measured over periods of one (years 1 to 2) to eleven (years 1 to 12) years, there is a tradeoff between the number of years and the number of branches that can be included in analysis. A two-year growth rate enables 675 branches to be evaluated and is still likely to be sufficiently long as to capture important growth patterns. Nonetheless, three-year post divestiture growth is examined for the 499 branches that have measurable growth rates for at least three years after being divested (that is, through year 4).

Four independent variables are included in the regression analysis. The first indicates whether the divested branch belonged to the surviving firm or not. As discussed, the Department of Justice generally insists that branches of the bank that is disappearing from the market, typically the target, be divested, because it is believed that runoff is likely to be less than it would be from a branch of a bank that would continue to operate and have branches elsewhere in the market. It would be fairly easy for customers of a divested branch of a surviving firm to close their accounts and reopen them at another, nearby branch of their old bank. Customers of banks that do not survive would not have that option, since their bank would no longer be operating, and therefore those customers are believed to be more likely to remain at the bank that purchased their branch. It is unclear whether branches of the surviving bank are more or less likely to exhibit faster growth in the years following the early runoff period, although customers of a divested survivor branch may always be somewhat more likely to switch banks, since they already have a familiarity with their old bank.

A dummy variable (SURVIVOR) is constructed that equals 1 if the divested branch belonged to the surviving firm and 0 otherwise. The surviving firm is defined by the name of the post-acquisition banking organization. In most cases, the acquirer is the survivor, but in two mergers, the surviving firm adopted the name of the target. In two other cases, the surviving firm adopted a new name that was neither the acquirer's nor the target's name. For all branches divested in these acquisitions, SURVIVOR equals 0.

The second dependent variable (INCNTY) is a dummy variable that equals 1 if a firm with an existing presence in the county purchased the divested branch and 0 otherwise. The Federal Reserve Board generally prefers that divestitures be sold to an out-of-market firm so that the total number of firms in the market remains unchanged following the merger. The Department of Justice, however, sometimes prefers that an in-market firm purchase divested 
offices, under the belief that such firms already know the market and can compete more effectively. As a result, runoff should be lower and subsequent growth higher when the branch purchaser is an institution that already has a presence in the county.

The size of the purchaser may also be an important characteristic affecting the ultimate success of a divestiture. Larger institutions may have more experience with and resources for purchasing, integrating, and managing newly acquired branches, which may enable them to better contain runoff and generate more growth than smaller institutions. In addition, customers may be more familiar with larger banks and therefore may be more willing to remain with them. Purchaser size (SIZE) is measured by total deposits of the firm (in billions of dollars) during the pre-merger period. ${ }^{15}$

Another characteristic of the purchaser that may influence its ability to stem runoff and grow deposits is whether it is a commercial bank or a thrift institution. Banks generally provide a wide range of services to both household and commercial customers, whereas thrifts are typically less active in serving commercial customers. As a result of serving a more narrow range of customers, many thrift institutions may find it more difficult to maintain and grow deposit levels than commercial banks. A dummy variable (THRIFT) is included that equals 1 if the purchaser was a thrift and 0 otherwise.

Consistent with Department of Justice preferences, firms that did not survive operated most of the divested branches in the sample, as less than 18 percent of the sample (131 branches) was originally owned by the surviving firm. There was a more even distribution among incounty and out-of-county firms, with 281 branches (37 percent) being sold to a firm that already had a presence in the county. Fairly large firms tended to purchase divested branches. The mean level of purchaser deposits was $\$ 8.9$ billion and the median was $\$ 4.6$ billion. Finally, about 20 percent of the sample (152 branches) included branches that were sold to thrift institutions.

Regression results are reported in table 7. Among the entire sample of 751 divested branches, none of the four right-hand side variables are statistically related to deposit growth between years 0 and 1 . This suggests that runoff has not been associated with certain key characteristics of the branch and the purchaser.

\footnotetext{
${ }^{15}$ If deposits from the pre-merger period are not available then deposits from the next closest time period are used to measure firm size.
} 
Table 7

Regression Results

\begin{tabular}{|c|c|c|c|c|c|}
\hline \multirow[b]{2}{*}{ Variable } & \multicolumn{5}{|c|}{ Coefficient Estimates (t-statistics in parentheses) } \\
\hline & $\begin{array}{c}\text { Dependent Variable: } \\
\text { Deposit growth from year } \\
0 \text { to year } 1, \text { less } \\
\text { benchmark growth } \\
\end{array}$ & \begin{tabular}{|c|} 
Dependent Variable: \\
Deposit growth from year \\
0 to year 1, less \\
benchmark growth \\
\end{tabular} & $\begin{array}{c}\text { Dependent Variable: } \\
\text { Deposit growth from year } \\
1 \text { to year } 3 \text {, less } \\
\text { benchmark growth } \\
\end{array}$ & $\begin{array}{c}\text { Dependent Variable: } \\
\text { Deposit growth from year } \\
0 \text { to year } 1 \text {, less } \\
\text { benchmark growth }\end{array}$ & $\begin{array}{c}\text { Dependent Variable: } \\
\text { Deposit growth from year } \\
1 \text { to year } 4 \text {, less } \\
\text { benchmark growth }\end{array}$ \\
\hline INTERCEPT & $\begin{array}{l}-14.49^{\mathrm{a}} \\
(-5.20)\end{array}$ & $\begin{array}{l}-11.96^{\mathrm{a}} \\
(-4.27)\end{array}$ & $\begin{array}{c}9.58^{\mathrm{c}} \\
(1.80)\end{array}$ & $\begin{array}{l}-11.24^{\mathrm{a}} \\
(-3.31)\end{array}$ & $\begin{array}{c}8.06^{\mathrm{c}} \\
(1.84)\end{array}$ \\
\hline SURVIVOR & $\begin{array}{r}-0.24 \\
(-0.05)\end{array}$ & $\begin{array}{r}-1.80 \\
(-0.38)\end{array}$ & $\begin{array}{r}-3.47 \\
(-0.38)\end{array}$ & $\begin{array}{r}-0.26 \\
(-0.05)\end{array}$ & $\begin{array}{r}0.70 \\
(0.09)\end{array}$ \\
\hline INCNTY & $\begin{array}{r}1.24 \\
(0.31)\end{array}$ & $\begin{array}{r}1.26 \\
(0.33)\end{array}$ & $\begin{array}{r}0.70 \\
(0.09)\end{array}$ & $\begin{array}{r}3.47 \\
(0.74)\end{array}$ & $\begin{array}{r}1.72 \\
(0.28)\end{array}$ \\
\hline SIZE & $\begin{array}{r}0.18 \\
(1.07)\end{array}$ & $\begin{array}{r}-0.04 \\
(-0.20)\end{array}$ & $\begin{array}{r}0.41 \\
(1.22)\end{array}$ & $\begin{array}{r}-0.13 \\
(-0.66)\end{array}$ & $\begin{array}{c}0.58 \\
(2.20) \mathrm{b}\end{array}$ \\
\hline THRIFT & $\begin{array}{r}4.63 \\
(0.92)\end{array}$ & $\begin{array}{r}2.84 \\
(0.58)\end{array}$ & $\begin{array}{r}6.48 \\
(0.70)\end{array}$ & $\begin{array}{r}5.76 \\
(0.92)\end{array}$ & $\begin{array}{r}-0.26 \\
(-0.03)\end{array}$ \\
\hline $\begin{array}{l}\text { Observations } \\
\text { R-Square }\end{array}$ & $\begin{array}{r}751 \\
0.01 \\
\end{array}$ & $\begin{array}{r}675 \\
0.00 \\
\end{array}$ & $\begin{array}{r}675 \\
0.01 \\
\end{array}$ & $\begin{array}{r}499 \\
0.00 \\
\end{array}$ & $\begin{array}{r}499 \\
0.01 \\
\end{array}$ \\
\hline $\begin{array}{l}\text { Sample } \\
\text { Restrictions }\end{array}$ & $\begin{array}{r}\text { All divested branches in } \\
\text { sample }\end{array}$ & $\begin{array}{r}\text { Sample branches that } \\
\text { survived at least } 3 \text { post- } \\
\text { divestiture years }\end{array}$ & $\begin{array}{r}\text { Sample branches that } \\
\text { survived at least } 3 \text { post- } \\
\text { divestiture years }\end{array}$ & $\begin{array}{r}\text { Sample branches that } \\
\text { survived at least } 4 \text { post- } \\
\text { divestiture years }\end{array}$ & $\begin{array}{r}\text { Sample branches that } \\
\text { survived at least } 4 \text { post- } \\
\text { divestiture years }\end{array}$ \\
\hline
\end{tabular}

Note: a (b,c) indicates significance at the 1 percent (5 percent, 10 percent) level. 
Although the coefficients are not significant, one cannot conclude that these characteristics are unrelated to deposit runoff. It may be the case, for example, that branches of nonsurviving banks generally yield less runoff. However, antitrust authorities, primarily the Department of Justice, may have only permitted branches of the survivor to be divested when it was felt that they could effectively retain and attract deposits. Likewise, the purchaser may have been willing to buy branches from a surviving firm only when it felt that the branches would experience limited deposit runoff. Unfortunately, the data do not allow us to determine whether the absence of a significant coefficient reflects no relationship, effective antitrust policy, or market-based discipline.

Regression results for divestiture growth between years 0 and 1 and between years 1 and 3 for the 675 branches that survived for at least three post-divestiture SOD dates are also reported in table 7 . The coefficients from the runoff regression equation are similar to those observed with the full sample and none are statistically significant. In addition, there are no significant coefficient estimates from the post-divestiture growth regression. Purchaser size was positively, yet not significantly related to deposit growth between years 1 and 3. The 499 branches that survived for at least four post-divestiture SOD dates generate similar results, except that the positive relationship between purchaser size and deposit growth is significant. This finding indicates that after the initial runoff, larger organizations were better than smaller ones at retaining and attracting deposits to divested branches. Large organizations may benefit from greater existing customer familiarity, being able to offer more products and services, superior ability to manage newly acquired facilities, being able to more effectively convert and support newly purchased offices, or being able to pay more to acquire the most attractive divested branches. Coefficients on the other independent variables are insignificant. ${ }^{16}$

\section{Conclusion}

Divestitures are an important element of the bank merger policies of antitrust authorities and bank regulators. By selling offices in markets that raise concerns about a substantial reduction of competition, acquiring firms can complete deals that otherwise might be considered antitrust violations. However, the question remains as to how effective divestitures are at

\footnotetext{
${ }^{16}$ Results are similar over the one-year period between the second and third post-divestiture SOD datesCoefficients are insignificant, except that growth was positively and significantly related to the size of the branch purchaser.
} 
promoting competition. The analysis in this paper sheds some light on this issue by examining the survival and growth rates experienced by a large sample of branches that were divested between 1989 and 1998.

Survival rate analysis indicates that divested offices are very likely to continue operating from year-to-year. The analysis also indicates that the probability of a divested branch operating for at least a certain number of years after divestiture is comparable to the probability of other similar branches operating over the same period of time.

Deposits at divested branches decline substantially during the period from shortly before the merger to shortly after the divestiture. Roughly 70 percent of the runoff that occurs during this time appears to be associated with the branch being acquired in a merger, and about 30 percent is associated with the branch being divested instead of operated by the acquiring firm. Substantial runoff suggests that the influence on the market of divested (and other acquired) branches may be smaller than indicated by pre-merger deposit levels. After the initial decline in deposits, divested branches grow their deposits at a comparable rate to other branches, suggesting that they can effectively retain and attract customers.

Cross-sectional analysis does not find any significant relationships between deposit runoff and various characteristics of the branch being sold or the firm that purchased it. Results based on post-divestiture growth are similar, with one exception—-post-divestiture deposit growth during the first three years following divestiture increases with the size of the purchaser, suggesting that large firms may be better able to retain and attract customers.

The findings of this paper suggest that the policy of antitrust authorities and bank regulators of accepting the divestiture of bank branches as a remedy for reducing the anticompetitive effect of certain mergers and acquisitions has been successful. Divested branches operate for lengths of time that are comparable to all branches, and even though they experience substantial deposit runoff around the time of the merger, divested branches subsequently exhibit deposit growth rates that are comparable to those of other similar branches. 


\section{References}

Berger, Allen, and Timothy Hannan (August 1998) "The Efficiency Cost of Market Power in the Banking Industry: A Test of the 'Quiet Life' and Related Hypotheses," Review of Economics and Statistics, pp. 454-465.

Burke, Jim (1998) "Divestiture as an Antitrust Remedy in Bank Mergers," Finance and Economics Discussion Series Working paper, Board of Governors of the Federal Reserve System.

Hannan, Timothy H. (February 1997) "Market Share Inequality, the Number of Competitors, and the HHI: An Examination of Bank Pricing," Review of Industrial Organization, pp. 23-35.

Hannan, Timothy H., and Nellie Liang (1995) "The Influence of Thrift Competition on Bank Business Loan Rates," Journal of Financial Services Research, 9, pp. 107-122.

Kamerschen, David R., and W. Scott Frame (February 1997) "The Profit-Structure Relationship in Legally Protected Banking Markets Using Efficiency Measures," Review of Industrial Organization, pp. 9-22.

Kramer, J. Robert II, and Erin Carter Grace, "Recent Issues Concerning Divestitures in Bank Mergers," handouts that accompanied presentation given on May 9, 2001 at a seminar sponsored by the Financial Institutions Committee of the Antitrust Section of the American Bar Association.

Neill, David S. (2001) "A Guide to the Policies and Procedures Affecting Antitrust Divestitures in Bank Mergers," Working paper.

Pilloff, Steven J. (March 1999) "Multimarket Contact in Banking," Review of Industrial Organization, pp. 163-182.

Pilloff, Steven J., and Stephen A. Rhoades (February 2002) "Structure and Profitability in Banking Markets," Review of Industrial Organization, pp. 81-98.

Prager, Robin, and Timothy H. Hannan (December 1998) "Do Substantial Horizontal Mergers Generate Significant Price Effects? Evidence from the Banking Industry," Journal of Industrial Economics, pp. 433-452.

Rhoades, Stephen A. (December 1995) "Market Share Inequality, the HHI, and Other Measures of the Firm-Composition of A Market," Review of Industrial Organization, pp. 657-674.

United States General Accounting Office (September 2002) "Federal Trade Commission: Study Needed to Assess the Effects of Recent Divestitures on Competition in Retail Markets," Report to Congressional Requesters. 